\title{
Case Reports in \\ Gastroenterology \\ Peritonitis following Endoscopy in a Patient on Peritoneal Dialysis with a Discussion of Current Recommendations on Antibiotic Prophylaxis
}

\author{
Amy L. Gould ${ }^{\mathrm{a}}$ Elie Chahla ${ }^{\mathrm{b}}$ Christine Hachem ${ }^{\mathrm{b}}$ \\ ${ }^{a}$ Saint Louis University School of Medicine, and ${ }^{b}$ Division of Gastroenterology and \\ Hepatology, Department of Internal Medicine, Saint Louis University School of Medicine, \\ St. Louis, Mo., USA
}

\section{Key Words}

Ascites · Endoscopy $\cdot$ Peritonitis · Prophylactic antibiotics

\begin{abstract}
Patients on peritoneal dialysis (PD) are at increased risk for peritonitis. We report a case of a patient with end-stage renal disease on continuous ambulatory PD (CAPD) who developed peritonitis within $24 \mathrm{~h}$ of upper endoscopy with biopsy and colonoscopy with polypectomy. He had a previous history of peritonitis unrelated to invasive procedures and eventually was transitioned to hemodialysis because of his recurrent peritonitis. The International Society for Peritoneal Dialysis (ISPD) and newly revised American Society for Gastrointestinal Endoscopy (ASGE) guidelines recommend prophylactic antibiotics for CAPD patients undergoing endoscopic procedures. Other guidelines do not address this issue, and there has been limited evidence to support recommendations.

(c) 2015 S. Karger AG, Basel
\end{abstract}

\section{Introduction}

Peritonitis is a common complication in patients on continuous ambulatory peritoneal dialysis (CAPD). Rates of peritonitis range from 0.06 episodes per year up to 1.66 episodes per year, depending on the institution [1]. Various mechanisms may cause peritonitis in 
Gould et al.: Peritonitis following Endoscopy in a Patient on Peritoneal Dialysis with a Discussion of Current Recommendations on Antibiotic Prophylaxis

these patients, including contamination from the skin, catheter-related infections, bacteremia, gynecologic sources, and bowel-source enteric organisms [1].

There are a variety of reasons that peritonitis as a complication of CAPD is clinically relevant. These include straightforward concerns such as increased morbidity, mortality, and healthcare costs. It is also important to consider less direct concerns such as the need to change dialysis modality from in-home CAPD to in-center hemodialysis (HD). In fact, the most common reason that patients change from CAPD to in-center dialysis is recurrent peritonitis [2]. This is important because there is evidence that patients on CAPD have outcomes that are possibly better than those of patients on in-center HD [3]. While there does not seem to be a significant difference in survival outcomes for these patients, there is a notable difference in patient satisfaction and quality of life [3]. In addition, the Medicare End Stage Renal Disease Program has multiple incentives in place to encourage the use of home dialysis methods over in-center HD [3]. Therefore, it is important to decrease the need to switch patients from home dialysis modalities, such as CAPD, to in-center HD. One way to do this would be to decrease the rate of peritonitis in patients on CAPD.

There is a notable correlation between invasive gastrointestinal procedures, such as endoscopy with and without polypectomy, and bowel-source peritonitis in patients on CAPD $[1,2]$. These infections likely arise due to transmural migration of bacteria from the bowel following manipulation of the gastrointestinal tract [1]. This translocation of bacteria is thought to cause a systemic bacteremia and eventual seeding of the peritoneal fluid [2]. Patients on CAPD are more likely to develop peritonitis following these procedures due to a variety of factors, especially patients with comorbid diabetes and constipation [1]. Additionally, the glucose-containing dialysis solution itself likely decreases host defenses by diluting host immune responses and likely promotes bacterial growth [2].

The International Society for Peritoneal Dialysis (ISPD) guidelines, as well as the newly updated American Society for Gastrointestinal Endoscopy (ASGE) guidelines, encourage the use of prophylactic antibiotics prior to endoscopy, as will be discussed below [1, 4]. These recommendations are based mainly on 2 retrospective studies of peritonitis in patients on CAPD following invasive procedures [5, 6]. However, no controlled studies exist investigating this issue.

Below, we report a case of a patient with end-stage renal disease (ESRD) on CAPD who developed peritonitis following both upper and lower endoscopy with polypectomy. He did not receive prophylactic antibiotics. Informed consent was obtained for this case report. We additionally review 9 case reports, 2 retrospective studies, and the current guidelines regarding the recommendations for the use of prophylactic antibiotics in patients on CAPD undergoing invasive gastrointestinal procedures.

\section{Case Presentation}

A 50-year-old African-American male with a past medical history of ESRD secondary to hypertension on CAPD, Enterococcus faecalis peritonitis 4 months prior to presentation, peptic ulcer disease, and treatment-naive chronic hepatitis $\mathrm{C}$ presented with diffuse abdominal pain 1 day after upper endoscopy (EGD) and colonoscopy with polypectomy. Approximately 1 week prior to presentation, the patient was seen in the outpatient gastroenterology clinic for intermittent left-sided abdominal pain. Because of his need for screening colonoscopy, the history of peptic ulcer disease, and abdominal pain, he was scheduled for an EGD and colonoscopy. He did not receive prophylactic antibiotics prior to the procedures. EGD was significant for clean-based duodenal ulcers. Biopsies were negative for Helicobacter pylori. 
Gould et al.: Peritonitis following Endoscopy in a Patient on Peritoneal Dialysis with a Discussion of Current Recommendations on Antibiotic Prophylaxis

Colonoscopy was performed to the sigmoid colon but could not be completed because of poor preparation. However, it was significant for 3 polyps in the rectosigmoid, removed with cold biopsy forceps (hyperplastic).

The patient reported feeling well immediately following the procedure but developed diffuse abdominal pain that evening. The next morning, he presented to the emergency room complaining of continued diffuse abdominal pain and cloudy dialysate fluid. On examination, he was afebrile. Abdominal examination was soft, nondistended, diffusely tender to palpation, with voluntary guarding but no rebound. His peritoneal dialysis (PD) catheter was in place with no tenderness on manipulation. Peritoneal fluid analysis revealed 22,500 white blood cells with $84 \%$ segmented neutrophils. Gram stain revealed multiple polymorphonuclear cells with no organisms. He was given IV vancomycin and cefepime and was transitioned to cefepime via a PD catheter. Over the course of his hospitalization, the patient's abdominal pain improved. He was discharged on hospital day 3 on a course of cefepime and vancomycin via PD. Cultures of peritoneal fluid grew vancomycin-sensitive coagulasenegative Staphylococcus.

\section{Discussion}

This case highlights a patient on CAPD with a history of peritonitis who developed peritonitis within $24 \mathrm{~h}$ of EGD with biopsy and colonoscopy with polypectomy. The patient's history of 2 episodes of peritonitis within 6 months of each other led to the decision to transition this patient from CAPD to HD. Recurrent peritonitis is a common reason to change from CAPD to HD [2]. While there is no difference in overall survival when comparing dialysis modalities such as CAPD to HD, there is a difference in the overall patient satisfaction and quality of life [3].

Review of the literature identifies 9 cases of peritonitis following colonoscopy in patients on CAPD (table 1). Patient ages ranged from 51-73 years, and $67 \%$ were female $(\mathrm{n}=$ 6/9). Seventy-eight percent of the patients in these cases were colonoscopies indicated for either rectal bleeding or positive hemoccult samples. Two patients developed peritonitis despite prophylactic antibiotics. Cultured bacteria were consistent with suspected enteric pathogens. The majority of cases did not have a previous history of peritonitis.

Two retrospective studies have investigated the use of prophylactic antibiotics in patients on CAPD undergoing invasive procedures. While peritonitis following endoscopy in patients on CAPD is a relatively infrequent event, there is a notable difference in the incidence of peritonitis in patients following endoscopic procedures (6.3-6.6\%) versus the general population $(<0.1 \%)[5,6]$. One study, conducted in Hong Kong in 2007, found that $6.3 \%$ of the patients who underwent a colonoscopy, both with and without polypectomy, developed peritonitis without prophylactic antibiotics, whereas none of the patients who received prophylactic antibiotics developed peritonitis [5]. A more recent and expanded retrospective study found that prophylactic antibiotics significantly reduced peritonitis in patients on CAPD following invasive non-EGD procedures. Invasive non-EGD procedures were defined as colonoscopy, sigmoidoscopy, enteroscopy, cystoscopy, hysteroscopy, and hysteroscopyassisted implantation or removal of intrauterine devices with biopsy, polypectomy or intrauterine device implantation [6].

The ISPD guidelines recommend drainage of peritoneal fluid and IV antibiotic prophylaxis with ampicillin, an aminoglycloside with or without metronidazole, prior to endoscopic procedures. The ASGE has recently released updated guidelines on antibiotic prophylaxis for GI endoscopy, which recommends the use of antibiotic prophylaxis for patients on CAPD 
Gould et al: Peritonitis following Endoscopy in a Patient on Peritoneal Dialysis with a Discussion of Current Recommendations on Antibiotic Prophylaxis

undergoing endoscopy of the lower GI tract [4]. They also suggest that the abdomen should be drained of fluid prior to any procedure involving the abdomen or pelvis.

It is important to note that neither the British Society of Gastroenterology (BSG) nor the European Society of Gastrointestinal Endoscopy (ESGE) address the issue of prophylactic antibiotics in patients on CAPD undergoing GI endoscopy $[7,8]$. The variable recommendations for prophylactic antibiotics is likely due to the low grade of evidence for the use of prophylactic antibiotics as most data rely on retrospective small studies. Gastroenterologist and nephrologists may differ in their approach to endoscopy in patients on CAPD. As no controlled studies exist, this merits opportunities for further study of the role of antibiotics in PD patients undergoing endoscopy. Understanding patient factors that may play a role in who is at risk may help risk stratify this population and prevent unnecessary complications.

\section{Disclosure Statement}

The authors declare that there are no conflicts of interest to disclose.

\section{References}

1 Piraino B, Bernardini J, Brown E, Figueiredo A, Johnson DW, Lye WC, Price V, Ramalakshmi S, Szeto CC: ISPD position statement on reducing the risks of peritoneal dialysis-related infections. Perit Dial Int 2011;31:614-630.

-2 Poortvliet W, Selten HP, Raasveld MH, Klemt-Kropp M: CAPD peritonitis after colonoscopy: follow the guidelines. Neth J Med 2010;68:377-378.

-3 Rivara MB, Mehrotra R: The changing landscape of home dialysis in the United States. Curr Opin Nephrol Hypertens 2014;23:586-591.

-4 ASGE Standards of Practice Committee, Khashab MA, Chithadi KV, Acosta RD, Bruining DH, Chandrasekhara V, Eloubeidi MA, Fanelli RD, Faulx AL, Fonkalsrud L, Lightdale JR, Muthusamy VR, Pasha SF, Saltzman JR, Shaukat A, Wang A, Cash B: Antibiotic prophylaxis for GI endoscopy. Gastrointest Endosc 2015;81:81-89.

5 Yip T, Tse KC, Lam MF, Cheng SW, Lui SL, Tang S, Ng M, Chan TM, Lai KN, Lo WK: Risks and outcomes of peritonitis after flexible colonoscopy in CAPD patients. Perit Dial Int 2007;27:560-564.

-6 Wu HH, Li IJ, Weng CH, Lee CC, Chen YC, Chang MY, Fang JT, Hung CC, Yang CW, Tian YC: Prophylactic antibiotics for endoscopy-associated peritonitis in peritoneal dialysis patients. PLoS One 2013;8:e71532.

-7 Allison MC, Sandoe JA, Tighe R, Simpson IA, Hall RJ, Elliott TS; Endoscopy Committee of the British Society of Gastroenterology: Antibiotic prophylaxis in gastrointestinal endoscopy. Gut 2009;58:869-880.

-8 Rey JR, Axon A, Budzynska A, Kruse A, Nowak A: Guidelines of the European Society of Gastrointestinal Endoscopy (E.S.G.E.) antibiotic prophylaxis for gastrointestinal endoscopy. European Society of Gastrointestinal Endoscopy. Endoscopy 1998;30:318-324.

-9 Petersen JH, Weesner RE, Gianella RA: Escherichia coli peritonitis after left-sided colonoscopy in a patient on continuous ambulatory peritoneal dialysis. Am J Gastroenterol 1987;82:171-172.

10 Verger C, Danne 0, Vuillemin F: Colonoscopy and continuous ambulatory peritoneal dialysis. Gastrointest Endosc 1987;33:334-335.

11 Holley J, Seibert D, Moss A: Peritonitis following colonoscopy and polypetcomy: a need for prophylaxis? Perit Dial Bull 1987;7:105-106.

12 Sprenger R, Neyer U: Enterococcus-peritonitis after endoscopic polypectomy: need for prophylactic antibiotics. Perit Dial Bull 1987;7:263.

13 Ray SM, Piraino B, Holley J: Peritonitis following colonoscopy in a peritoneal dialysis patient. Perit Dial Int 1990;10:97-98.

14 Bac DJ, van Blankenstein M, de Marie S, Fieren MW: Peritonitis following endoscopic polypectomy in a peritoneal dialysis patient: the need for prophylaxis. Infection 1994;22:220-221.

-15 Lin YC, Lin WP, Huang JY, Lee SY: Polymicrobial peritonitis following colonoscopic polypectomy in a peritoneal dialysis patient. Intern Med 2012;51:1841-1843. 


\section{Case Reports in
Gastroenterology}

\begin{tabular}{l|l}
\hline \multicolumn{2}{l}{ Case Rep Gastroenterol 2015;9:302-306 } \\
\hline DOI: 10.1159/000437291 & $\begin{array}{l}\text { ○ 2015 S. Karger AG, Basel } \\
\text { www.karger.com/crg }\end{array}$ \\
\hline
\end{tabular}

Gould et al:: Peritonitis following Endoscopy in a Patient on Peritoneal Dialysis with a Discussion of Current Recommendations on Antibiotic Prophylaxis

Table 1. Peritonitis following colonoscopy with and without polypetcomy in patients on continuous ambulatory peritoneal dialysis

\begin{tabular}{|c|c|c|c|c|c|c|c|c|}
\hline First author [ref.], year & $\begin{array}{l}\text { Age/ } \\
\text { sex }\end{array}$ & $\begin{array}{l}\text { Duration } \\
\text { of CAPD }\end{array}$ & $\begin{array}{l}\text { Indication for } \\
\text { colonoscopy }\end{array}$ & $\begin{array}{l}\text { Poly- } \\
\text { pectomy }\end{array}$ & $\begin{array}{l}\text { Time to } \\
\text { infection, } \mathrm{h}\end{array}$ & $\begin{array}{l}\text { Cultured } \\
\text { microorganism(s) }\end{array}$ & $\begin{array}{l}\text { Prophylaxis } \\
\text { given }\end{array}$ & $\begin{array}{l}\text { Previous history of } \\
\text { peritonitis noted }\end{array}$ \\
\hline Peterson [9], 1987 & $69 / \mathrm{M}$ & - & F/U previously seen polyps & - & 36 & Escherichia coli & - & + \\
\hline Verger [10], 1987 & $65 / \mathrm{M}$ & 1 year & rectal bleeding & + & 24 & E. coli & - & - \\
\hline Holley [11], 1987 & $69 / \mathrm{F}$ & - & positive hemoccult & + & 24 & E. coli & - & - \\
\hline Sprenger [12], 1987 & $54 / \mathrm{F}$ & 1 year & positive hemoccult & + & 72 & Enterococcus & $+a$ & - \\
\hline Ray [13], 1990 & $65 / F$ & - & rectal bleeding & + & 24 & $\begin{array}{l}\text { Nonfragilis bacteroides } \\
\text { (4 species) }\end{array}$ & $+\mathrm{b}$ & - \\
\hline Bac [14], 1994 & $51 / \mathrm{F}$ & 4 years & fecal blood loss & + & 24 & $\begin{array}{l}\text { Peptostreptococcus } \\
\text { asaccharolyticus } \\
\text { Bacteroides disens } \\
\text { B. ureolyticus }\end{array}$ & - & - \\
\hline Poortvliet [2], 2010 (a) & $67 / F$ & 4 years & rectal bleeding & + & 48 & E. coli & - & + \\
\hline Poortvliet [2], 2010 (b) & $73 / \mathrm{M}$ & 4 years & rectal bleeding & + & 48 & $\begin{array}{l}\text { E. coli } \\
\text { Klebsiella oxytoca } \\
\text { Enterococcaceae }\end{array}$ & - & - \\
\hline Lin [15], 2012 & $53 / \mathrm{F}$ & 4 years & $\begin{array}{l}\text { history of colonic polyps } \\
\text { and elevated CEA }\end{array}$ & + & 24 & $\begin{array}{l}\text { E. coli } \\
\text { K. pneumoniae } \\
\text { E faecalis }\end{array}$ & - & - \\
\hline
\end{tabular}

$\mathrm{F} / \mathrm{U}=$ Follow-up; $\mathrm{CEA}=$ carcinoembryonic antigen .

a Intraperitoneal cephalothin; b intravenous vancomycin and gentamycin. 